\title{
Proximal Interruption of Right Pulmonary
Artery in an Adult Patient Presenting with Hemoptysis
}

\author{
Hemoptizi ile Başvuran Yetişkin Bir Hastada Sağ Pulmoner Arter \\ Proksimalinde Kesinti
}

Mustafa Belal Hafeez Chaudhry', Kumail Khandwala', Wasim Ahmed Memon', Taha Sheikh², Tanveer UI Haq', Muhammad Arif Saeed'

\section{Abstract}

A 42 year old lady presented with dyspnea and 3 episodes of hemoptysis since 1 day. Her chest radiograph revealed mild peripheral fibrosis \& volume loss in right lung, subsequent HRCT confirmed the findings with additional diagnosis of absence of the right main pulmonary artery. This was further confirmed on digital subtraction angiography and the right lung was solely supplied by the systemic circulation. The conventional angiography did not demonstrate any active extravasation or blush to suggest active bleeder. Empirical embolization was not attempted due to a risk of pulmonary infarction. Patient was managed symptomatically and conservatively. This condition is important to recognize in the list of differential diagnoses for pulmonary artery abnormalities and any acquired causes of pulmonary vasculature obstruction must be ruled out on imaging modalities.

Key words: Proximal Interruption of Pulmonary Artery (PIPA), High Resolution Computed Tomography (HRCT), Digital Subtraction Angiography (DSA).

\section{Özet}

Kırk iki yaşında kadın hasta, önceki günden beri 3 kez hemoptizi atağı ve dispne yakınması ile başvurdu. Akciğer grafisinde sağ akciğerde volüm kaybı ve hafif periferal fibrozis vardı. Yüksek rezolüsyonlu bilgisayarlı tomografide bu bulgulara ilave olarak sağ pulmoner arterin olmadığı belirlendi. Bu bilgi dijital subtraction anjiografi ile doğrulandı ve sağ akciğerin sadece sistemik dolaşımdan beslendiği görüldü. Konvansiyonel angiografide herhangi bir ekstra damarlanma veya aktif kanama odağı görülmedi. Pulmoner enfarkt riski nedeniyle ampirik embolizasyon yapılmadı. Hasta semptomatik ve konservatif olarak tedavi edildi. Pulmoner arter anomalilerinin ayırcı tanısında bu durum önemli olup görüntüleme yöntemleri ile pulmoner damarsal obstrüksiyonların nedenleri araştırılmalıdır.

Anahtar Sözcükler: Pulmoner arter kesintisi, yüksek çözünürlüklü bilgisayarlı tomografi, dijital anjiografi.
Proximal Interruption of the pulmonary artery (PIPA) is an uncommon vascular developmental anomaly with a prevalence of 1 in 200,000 and a median age of diagnosis at 14 years (1). It is more commonly found with other cardiovascular anomalies; the prognosis is poor in such cases. PIPA is impor- tant to recognize in the differential diagnosis of pulmonary artery anomalies, since there are no consistent guidelines regarding the management. In asymptomatic patients, some clinicians adopt conservative management with close follow-up. Others seek to restore a physiological pulmonary

'Department of Radiology, Aga Khan University, Karachi, Pakistan

${ }^{2}$ Department of Medicine, Dow University of Health Sciences,

Karachi, Pakistan

${ }^{1}$ Aga Khan Üniversitesi, Radyoloji Bölümü, Karachi, Pakistan 2Dow Sağlık Bilimleri Üniversitesi, Tıp Fakültesi, Karachi, Pakistan

Submitted (Başvuru tarihi): 07.1 1.2017 Accepted (Kabul tarihi): 15.01.2018

Correspondence (iletişim): Kumail Khandwala, Department of Radiology, Aga Khan University, Karachi, Pakistan

e-mail: kumail.khandwala@gmail.com 
functionality via early revascularization of the interrupted pulmonary artery and embolization of any ruptured collateral vessels if symptoms warrant it. This report is a description of a case of a previously asymptomatic middle-aged woman with right-sided PIPA, who had an insignificant past history and presented with dyspnea and episodes of painless hemoptysis.

\section{CASE}

A 42-year-old woman presented at the emergency department (ED) with dyspnea and 3 episodes of hemoptysis (approximately half a cup in volume) since the previous day. There was no associated chest pain, fever, night sweats, or weight loss. Her medical history was only remarkable for hypertension, which was controlled with losartan (angiotensin receptor blocker). She had similar asymptomatic episodes of hemoptysis 4 years earlier, for which no detailed work-up was done. There was a family history of diabetes mellitus and gastrointestinal malignancy. The patient did not provide any history of tuberculosis contact. On physical examination, the patient's vital signs were stable and a systemic examination was unremarkable. Normal air entry and heart sounds were heard on chest auscultation.

A routine laboratory workup was performed through the ED. Her baseline hemoglobin level, at the time of first episode of hemoptysis, was $12.2 \mathrm{~g} / \mathrm{dL}$ (11.1-14.5) which dropped to $10.1 \mathrm{~g} / \mathrm{dL}(11.1-14.5)$ over the period of 2 days. A decrease in hematocrit level from $38.7 \%$ to $34.4 \%$ (35.4-42.0) was also noted. The total leucocyte count was normal: $9.6 \times 109 / \mathrm{L}$ (4.0-10.0), platelet count was normal: $323 \times 109 / \mathrm{L}$ (150-400), peripheral film showed normochromic and normocytic red blood cells, prothrombin time was of 10.5 seconds (9.1-13.1) with an international normalization ratio of 1.0, and the activated partial thromboplastin time was 23.9 seconds (22.9. 34.5).

A local ear, nose, throat examination and bronchoscopy were performed, and did not reveal any active site of bleeding. Sputum and bronco-alveolar lavage (BAL) specimens were sent for Gram-stain and bacterial cultures, which turned out to be negative. A smear for fungal hyphae, and an acid-fast bacilli (AFB) smear along with AFB culture were also negative for both specimens. Mycobacterium tuberculosis complex was not detected with a GeneXpert MTB/RIF assay (Cephaid, Sunnyvale, CA, USA) of specimens of both sputum and BAL.

A posteroanterior chest radiograph revealed volume loss within the right hemithorax with slight elevation of the right hemidiaphragm. The heart and the mediastinum were shifted toward the ipsilateral right side. The left lung was relatively hyperinflated. The right hilum was not well visualized. There was some pleural thickening in the right lung apex, and fine reticular shadowing with a suggestion of rib notching was observed (Figure 1).

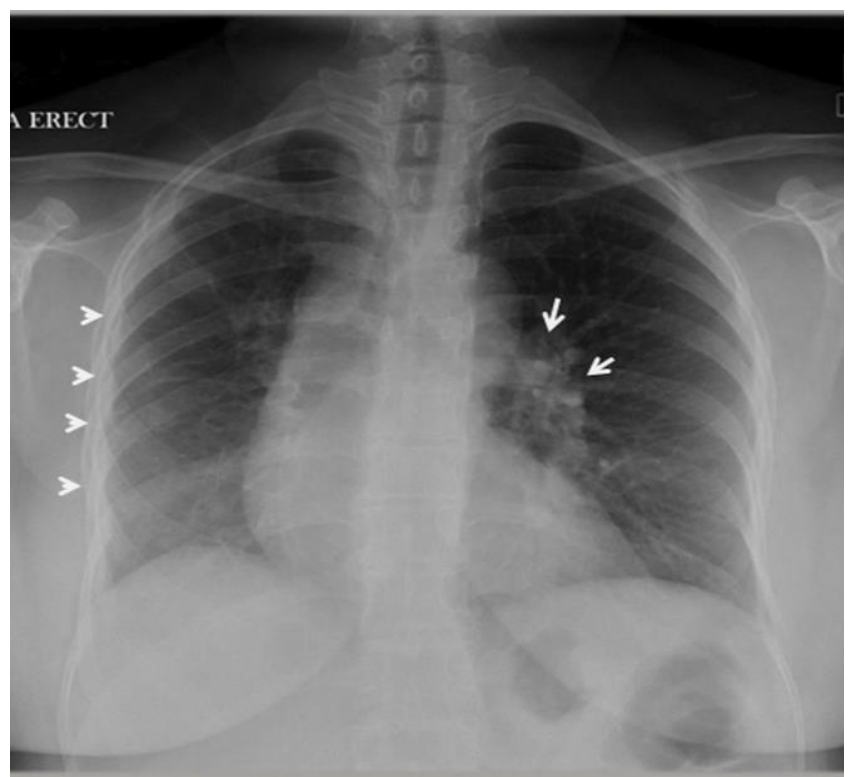

Figure 1: The right hilum is not visualized with right lung volume loss and slightly elevated right hemidiaphragm. Some pleural thickening (arrow heads) on right side with fine reticular shadowing and suggestion of rib notching. Ipsilateral right sided mediastinal shift with engorged left hilum (white arrows)

Subsequently, a high resolution computed tomographic (HRCT) scan of chest was obtained during the patient's stay in the hospital to delineate the suspected pulmonary pathology. A hypoplastic right lung with volume loss, septal fibrosis, honeycombing, and subpleural cysts, predominantly in the base, were observed. Compensatory marked hyperinflation of the left lung was noted, which also slightly herniated toward the right side. Mediastinal window settings revealed the presence of the prominent left main pulmonary artery and its divisions; however, the complete absence of the right main pulmonary artery was noted (Figure 2). Further characterization of the pulmonary vasculature was not possible as it was an unenhanced scan. The radiologist advised further evaluation and management with digital subtraction angiography (DSA) of the pulmonary and bronchial arteries. Subsequent DSA confirmed the HRCT findings of right-sided proximal Interruption of the pulmonary artery (PIPA) (Figure 3a). The main pulmonary artery and left pulmonary artery appeared dilated. The origin of the right pulmonary artery was not identified. This was followed by an angiogram of the right subclavian artery and bronchial arteries, 
which revealed numerous collaterals predominantly arising from the lateral thoracic, internal mammary artery and the thyrocervical trunk supplying the right lung (Figures 3 b-d). Empirical embolization of the arteries supplying right upper lobe was not performed due to a presumed risk of pulmonary infarction/necrosis.

The patient was given symptomatic treatment and started on tranexamic acid and cefpodoxime and remained stable with no further episodes of hemoptysis. She was discharged and was followed up as an outpatient for 3 months without any active complaint.

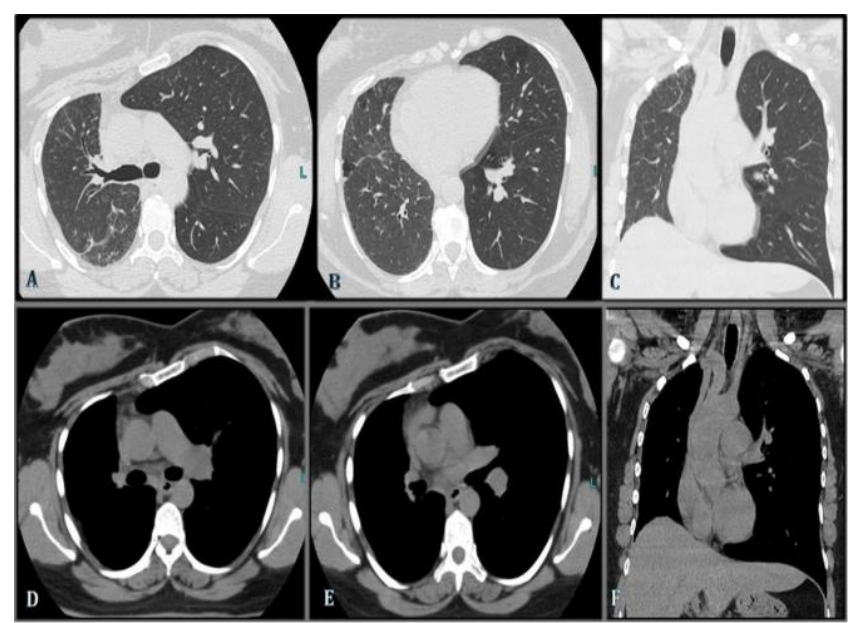

Figure 2: Lung Window $(A, B, C)$ shows hypoplastic right lung with volume loss, septal fibrosis, minimal honeycombing and subpleural cysts predominantly in the base. Compensatory hyperinflation of the left lung with slight right sided herniation. Mediastinal Window $(D, E, F)$ reveals complete absence of the right main pulmonary artery with prominent left main pulmonary artery and its divisions

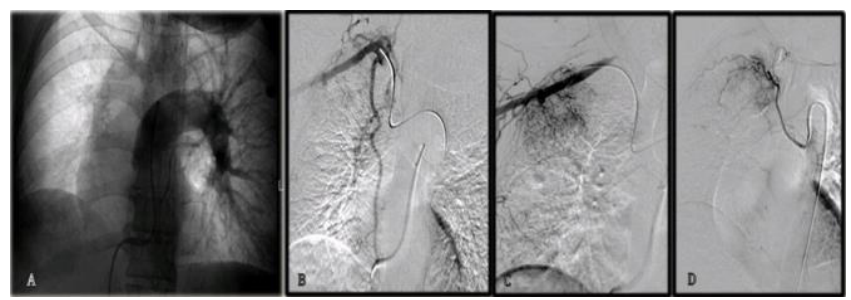

Figure 3: Native Conventional Pulmonary Angiogram (A) demonstrating proximal interruption of right branch of pulmonary artery with dilated main pulmonary artery trunk and left branch. DSA of the right subclavian artery $(B, C)$ and bronchial arteries (C) revealing numerous collaterals arising from the lateral thoracic, internal mammary artery and thyrocervical trunk supplying the right lung

\section{DISCUSSION}

PIPA, formerly known as unilateral absence of pulmonary artery, is an uncommon vascular developmental anomaly $(2,3)$. It has a prevalence of 1 in 200,000 , with a median age of diagnosis of an isolated form of interruption of the pulmonary artery at 14 years (range: 0.1 to 58 years) ( 1 ). In a review by Pool et al. (4), it was found as an isolated finding in about one-third of the cases; it is more commonly found associated with other cardiovascular abnormalities. Left-sided PIPA is frequently associated with right-sided aortic arch and other congenital cardiovascular anomalies, such as septal defects, transposition of the great arteries, congenitally corrected transposition, vascular intramural pathologies (coarctation of the aorta, subvalvular aortic stenosis, pulmonary stenosis), or combinations and syndromes (Tetralogy of Fallot, Taussig-Bing anomaly, coarctation, scimitar syndrome) $(1,5)$. However, right-sided PIPA is more often (63\%) associated with a normal left-sided aortic arch (1). No genetic markers have been linked with any of these disorders.

PIPA can potentially be caused by any involution of the proximal sixth aortic arch during the first 16 weeks of intrauterine development. This aberrancy may result in termination of the extrapulmonary portion of the affected pulmonary artery within $1 \mathrm{~cm}$ of its origin. However, the intrapulmonary vessels are usually patent and normal in distribution (5). In that case, intrapulmonary arteries derive their blood supply from other systemic collateral vessels, namely, the intercostal, internal mammary, subclavian, and innominate arteries, and from the bronchial artery system. These transpleural and bronchial vessels interconnect extensively with the intrapulmonary vessels via microvascular communications (6). In a review of the literature performed by Harkel et al. (1), the general pattern observed for PIPA was on the side opposite to the aortic arch.

PIPA should be differentiated from similar conditions, especially in the presence of a small hemithorax, which may obviate reconsidering the diagnosis. Hypogenetic lung syndrome is characterized by a linear shadow representing the anomalous draining vein (scimitar sign); however, the normal bronchial branching pattern of PIPA differentiates it from hypogenetic lung syndrome. A small lung may also appear hyperlucent, creating potential confusion with Swyer-James syndrome (post-infectious obliterative bronchiolitis), which also demonstrates trapped air on radiography during expiration secondary to bronchiectasis (6). The normal caliber of the pulmonary vessels with normal architecture differentiates this condition from PIPA. In the differential diagnosis of acquired causes of pulmonary vasculature obstruction, conditions like Takayasu arteritis, chronic pulmonary thromboembolism, and mediastinal fibrosis must be ruled out. The clinical symptomatology of PIPA varies, depending on the extent of anomalies and associated defects. The symptomatology may include shortness of breath, recur- 
rent pulmonary infections (37\%), dyspnea, limited exercise tolerance $(40 \%)$, hemoptysis $(20 \%)$, (1) or other symptoms of pulmonary hypertension or heart failure $(5,7)$. Hemoptysis occurs secondary to the rupture of hypertrophied collateral vessels between the pulmonary and systemic vasculature (8). All symptoms aside, pulmonary hypertension alone, with a reported incidence of $19 \%$ to $44 \%,(1,4)$ is the most important determinant of long-term survival prognosis, followed by hemoptysis. The overall mortality is reported as $7 \%$ per year after diagnosis (1).

Most congenital anomalies of the pulmonary arteries in adults are found incidentally on chest radiographs or CT scans. The most consistent findings on chest radiography include an ipsilateral hypoplastic hilum, varying degrees of pulmonary hypoplasia (hypolucent and containing small and fewer alveoli, secondary to low oxygen tension), and an ipsilateral shift of the heart and mediastinum toward the affected side (9). This is accompanied by a prominent contralateral hilum (owing to the entire right ventricular output going preferentially toward the uninterrupted pulmonary artery) and consequent compensatory hyperinflation of the contralateral lung (5).

The mediastinal portion of the affected pulmonary artery may terminate within $1 \mathrm{~cm}$ of its origin or may not be visible on a CT scan (9). Magnetic resonance imaging may be of greater advantage compared with other modalities to delineate the vascular anatomy in addition to identifying associated congenital cardiac abnormalities and limiting ionizing radiation exposure in any age group. The collateral transpleural arteries may appear perpendicular to the pleural surface as multiple linear opacities, and a characteristic serrated pleural and subpleural parenchymal thickening may be delineated in a soft tissue window because of the enlarged intercostal collaterals due to direct anastomosis of transpleural collateral vessels with peripheral branches of the pulmonary artery. Owing to hypoxic vasoconstriction, a mosaic pattern may be observed secondary to underperfusion in the affected lung, and overperfusion may be seen in the unaffected lung. This may be best seen with HRCT, as in our case. Other signs of collateral arteries, such as rib notching, may be identified when the intercostal arteries are involved, in addition to increased subpleural interstitial lung marking. The CT scan is essential to map out a normal bronchial branching pattern (9).

There are no consistent guidelines regarding the management of isolated interruption of the pulmonary artery. In asymptomatic patients, some clinicians adopt con- servative management with close follow-up. Others seek to restore physiological pulmonary functionality via early revascularization of the interrupted pulmonary artery and embolization of any ruptured collateral vessels, if symptoms warrant it $(5,7,8,10)$.

\section{CONCLUSION}

PIPA is an uncommon vascular condition. It may be an isolated finding, or more commonly, it is seen with other cardiovascular anomalies. Depending on the extent of any associated anomalies, patients with this condition who survive into adulthood can present with pulmonary hypertension, hemoptysis, recurrent respiratory infections, dyspnea, etc., or may remain asymptomatic. This condition is important to recognize in the list of differential diagnoses for pulmonary artery abnormalities, and any acquired causes of pulmonary vasculature obstruction must be ruled out with imaging modalities.

\section{CONFLICTS OF INTEREST}

None declared.

\section{AUTHOR CONTRIBUTIONS}

Concept - M.B.H.C., K.K., W.A.M., T.S., T.U.H., M.A.S.; Planning and Design - M.B.H.C., K.K., W.A.M., T.S., T.U.H., M.A.S.; Supervision - M.B.H.C., K.K., W.A.M., T.S., T.U.H., M.A.S.; Funding - W.A.M., T.U.H.; Materials - T.U.H., M.A.S.; Data Collection and/or Processing M.B.H.C., T.S., K.K.; Analysis and/or Interpretation M.B.H.C., K.K.; Literature Review - K.K., T.S.; Writing M.B.H.C., T.S., K.K.; Critical Review - M.B.H.C., K.K.

\section{YAZAR KATKILARI}

Fikir - M.B.H.C., K.K., W.A.M., T.S., T.U.H., M.A.S.; Tasarım ve Dizayn - M.B.H.C., K.K., W.A.M., T.S., T.U.H., M.A.S.; Denetleme - M.B.H.C., K.K., W.A.M., T.S., T.U.H., M.A.S.; Kaynaklar - W.A.M., T.U.H.; Malzemeler - T.U.H., M.A.S.; Veri Toplama ve/veya İşleme M.B.H.C., T.S., K.K.; Analiz ve/veya Yorum - M.B.H.C., K.K.; Literatür Taraması - K.K., T.S.; Yazıyı Yazan M.B.H.C., T.S., K.K.; Eleştirel İnceleme - M.B.H.C., K.K.

\section{REFERENCES}

1. Ten Harkel AD, Blom NA, Ottenkamp J. Isolated unilateral absence of a pulmonary artery: a case report and review of the literature. Chest 2002; 122:1471-7. [CrossRef] 
2. Fraentzel O. Ein Fall von abnormer Communication der: Aorta mit der Arteria pulmonalis. Virchows Archiv 1868; $1: 420-6$. [CrossRef]

3. Shakibi JG, Rastan H, Nazarian I, Paydar M, Aryanpour I, Siassi B. Isolated unilateral absence of the pulmonary artery. Review of the world literature and guidelines for surgical repair. Jpn Heart J 1978; 19:439-51.

4. Pool PE, Vogel JH, Blount SG Jr. Congenital unilateral absence of the pulmonary artery. The importance of flow in pulmonary hypertension. Am J Cardiol 1962; 10:70632.

5. Castañer E, Gallardo X, Rimola J, Pallardó Y, Mata JM, Perendreu J, et al. Congenital and acquired pulmonary artery anomalies in the adult: radiologic overview. Radiographics 2006; 26:349-71. [CrossRef]

6. Morgan PW, Foley DW, Erickson SJ. Proximal interruption of a main pulmonary artery with transpleural collateral vessels: CT and MR appearances. J Comput Assist Tomogr 1991; 15:311-3. [CrossRef]
7. Welch K, Hanley F, Johnston T, Cailes C, Shah MJ. Isolated unilateral absence of right proximal pulmonary artery: surgical repair and follow-up. Ann Thorac Surg 2005; 79:1399-402. [CrossRef]

8. Reñé M, Sans J, Dominguez J, Sancho C, Valldeperas J. Unilateral pulmonary artery agenesis presenting with hemoptysis: treatment by embolization of systemic collaterals. Cardiovasc Intervent Radiol 1995; 18:251-4.

9. Ryu DS, Spirn PW, Trotman-Dickenson B, Hunsaker A, Jung SM, Park MS, et al. HRCT findings of proximal interruption of the right pulmonary artery. J Thorac Imaging 2004; 19:171-5. [CrossRef]

10. Liu B, Monroe EJ, Kogut MJ. Proximal interruption of the pulmonary artery: Transcatheter embolization for emergent management of massive hemoptysis. Radiol Case Rep 2015; 8:865. [CrossRef] 